\title{
The Porosity Evaluation with Using Image Analyser Software in Aluminium Cast Alloys
}

\section{Lenka Kuchariková, Eva Tillová, Juraj Belan, Denisa Závodská, Ivana Švecová}

Faculty of Mechanical Engineering, University of Žilina. Univerzitná 8215/1, 01026 Žilina. Slovakia. E-mail: lenka.kucharikova@fstroj.uniza.sk, eva.tillova@fstroj.uniza.sk, juraj.belan@fstroj.uniza.sk,denisa.zavodska@fstroj.uniza.sk, ivana.svecova@fstroj.uniza.sk,

\begin{abstract}
Aluminium castings have played an integral role in the growth of the aluminium industry since its inception in the late $19^{\text {th }}$ century. The Al-Si-Cu alloys are the most versatile materials, comprising $85-90 \%$ of the total aluminium cast parts produced by the automotive industry due to their highest strength to weight ratio, good thermal conductivity, excellent fluidity, hot tear resistance and feeding characteristics which allow casting intricate shapes such as engine blocks, cylinder head sore chassis components and so on. Whereas these parts are made by casting the porosity evolution is important, in order to secure the best mechanical properties of these casts. Therefore this work is focused on evolution the porosity in Al-Si-Cu cast alloys using light metallography microscopy and image analyser software. The evolution shows that the experimental material casted into the metallic mould had about $98.78 \%$ smaller porosity size in comparison to the material casted into the sand mould, therefore it showed better properties.
\end{abstract}

Keywords: Porosity, Aluminium alloy, Image analyser software, Metallic mould, Sand mould

\section{Acknowledgement}

This work has been supported by The Scientific Grant Agency of the Ministry of Education of the Slovak Republic $N^{o}$ 1/0533/15, $N^{o} 044 \check{Z} U-4 / 2014$.

\section{References}

[1] https://www.linkedin.com/pulse/automotive-parts-die-casting-interim-solution-green-rohith-sampathi (accessed June 2016)

[2] TIllovÁ, E., HURTAlOVÁ, L., CHAluPOVÁ, M., ĎURINÍKOVÁ, E. (2010). Quality control of secondary (recycled) Al-Si cast alloy. In: Toyotarity - Structure of control elements importance: monography. (Yurij V. Makovetsky, (Ed.)), pp. 48-63. Dnipropetrovsk.

[3] http://www.teksidaluminum.com/pdf/20-1-1.pdf (accessed May 2016)

[4] ROSSO, M. (2005). The influence of casting process on quality and performances on Al based automotive components. In: Proceeding of 13th International scientific conference on Achievements in mechanical and materials engineering, pp. 547 - 550. Poland, Gliwice.

[5] PUCHER, P., BÖTTCHER, H., KAUFMANN, H., ANTREKOWITSCH, H., UGGOWITZER, P.J. (2011). Mechanical properties and casting characteristics of the secondary aluminium alloy AlSi9Cu3(Fe) (A226). In: Supplemental Proceedings: Materials Fabrication, properties, characterization, and modelling. The mminerals, metals \& materials soviety, Vol. 2, pp. 237-244.

[6] ŤAVODOVÁ, M., KALINCOVÁ. D. (2016). Improving the Quality of Castings Using Thermovision. In: Manufacturing Technology, Vol. 16, No. 1, pp. 268-273.

[7] SHAHA, S.K., CZERWINSKI, F., KASPRZAK, W., FRIEDMAN, J., CHEN, D.L. (2016). Effect of Cr, Ti, V, and $\mathrm{Zr}$ micro-additions on microstructure and mechanical properties of the Al-Si-Cu-Mg cast alloy. In: Metallurgical and Materials Transactions A: Physical Metallurgy and Materials Science, Vol. 47, No. 5, pp. 2396-2409.

[8] HURTAlOVÁ, L., TIllovÁ, E., CHAlUPOVÁ, M. (2012). Mechanical properties of heat treated secondary AlSi12Cu1Fe cast alloy at room temperature. Communications: scientific letters of the University of Žilina, Vol. 14, No. 4, pp. 11-18.

[9] HURTAlOVÁ, L., TILlOVÁ, E. (2013). Elimination of the negative effect of Fe-rich intermetallic phases in secondary (recycled) aluminium cast alloy. Manufacturing Technology, Vol. 13, No. 1, pp. 44-50.

[10] HURTAlOVÁ, L., TILlOVÁ, E., CHALUPOVÁ, M. (2014). Optimization of eutectic Si particles morphology in secondary Al-Si cast alloys after different heat treatment. Advanced Materials Research, Vol. 1025-1026, pp. 349-354.

[11] SKOČOVSKÝ, P., BENKO, P., VAŠKO, A. (2000). Quantitative appreciation of structure and fracture surface of casting materials. In: Proccedings of Advanced manufacturing and repair technologies in vehicle industry, pp. 51-55 Zielona Góra - Łagów, Poland. 
[12] AMMAR, H.R., SAMUEL, A.M., SAMUEL, F.H. (2008). Porosity and the fatigue behavior of hypoeutectic and hypereutectic aluminum-silicon casting alloys. International Journal of Fatigue, Vol. 30, pp. 1024-1035

[13] http://www.totalmateria.com/page.aspx?ID=Articles\&LN=EN (accessed May 2016)

[14] http://digitool.library.mcgill.ca/R/?func=dbin-jump-full\&object_id=28732\&local_base=GEN01-MCG02 (accessed May 2016)

[15] ZUO, Y., LI, H., XIA, M., JIANG, B., SCAMANS, G.M., FAN, Z. (2011). Refining grain structure and porosity of an aluminium alloy with intensive melt shearing. Scripta Materialia, Vol. 64, pp. 209-212.

[16] PALYGA, L., STACHOWICZ, M., GRANAT, K. (2016). Influence of High-presure-die-casting second stage parameter on structure of AlSi9Cu3(Fe) alloy. Manufacturing technology, Vol. 16, No. 2, pp. 410-416.

[17] ANSON, J. P., GRUZLESKI, J. E. (1999). The Quantitative Discrimination between Shrinkage and Gas Microporosity in Cast Aluminum Alloys Using Spatial Data Analysis. Materials characterization, Vol. 43, pp. 319-335.

[18] GONZÁlEZ, R., GONZÁLEZ, A., TALAMANTES-SILVA, J., VALTIERRA, S., MERCADO-SOLÍS, R.D., GARZA-MONTES-DE-OCA, N.F., COLÁS, R. (2013). Fatigue of an aluminium cast alloy used in the manufacture of automotive engine blocks. International Journal of Fatigue, Vol. 54, pp. 118-126.

[19] BOLIBRUCHOVÁ, D., RICHTÁRECH, L. (2016). Possibilities of using Al-Si-Mg alloys with higher Fe content for demanding castings. Manufacturing technology, Vol. 16, No. 2, pp. 317-323

[20] NOVÝ, F., KOPAS, P., BOKU゚VKA, O., SAVIN, A. (2016). Fatigue durability of ductile iron in very-high-cycle region. Manufacturing technology, Vol. 16, No. 2, pp. 406-409.

[21] SEIFEDINE S., JOHANSSON S., SVENSSON I. (2008). The influence of cooling rate and manganese content on the $\beta$-Al5FeSi phase formation and mechanical properties of Al-Si - based alloys. Materials Science and Engineering A, Vol. 490, pp. 385-390.

[22] MOUSTAFA M. A. (2009). Effect of iron content on the formation of B-Al5FeSi and porosity in Al-Si eutectic alloys. Journal of Materials Processing Technology, Vol. 209, pp. 605-610.

[23] FUKASAWA, K., MOHRI, R., OHTAKE, T., INOUE, T., KURODA, A., KAMBE, H., YOSHIDA, M. (2016). Effect of Mn addition on the age-hardening behavior of an Al-(9-10)\%Si-0.3\% Mg die casting alloy in T5 and T6 heat treatment. Materials Transactions, Vol. 57, No. 6, pp. 959-965.

[24] LU, L., DAHLE, A.K. (2005). Iron-rich intermetallic phases and their role in casting defect formation in hypoeutectic Al-Si Alloys. Metallurgical and materials transactions A, Vol. 36A, pp. 819-835.

[25] STN EN ISO 6892-1:2010 (42 0310) Metallic materials. Tensile testing. Part 1: Method of test at ambient temperature.

[26] STN EN ISO 6506-1:2015 (42 0371) Metallic materials. Brinell hardness. Part 1: Test method.

[27] RIOS, C. T., CARAM, R., BOLFARINI, C., BOTTA, W.J., KIMINAMI, C.S. (2003). Intermetallic compounds in the Al-Si-Cu system. Acta Microscopia, Vol. 12, pp. 77-82.

[28] CAMPBELL, J., HARDING R.A. (1994). Solidification Defects in Castings. TALAT Lecture 3207, EAA - European Aluminium Association. 